\title{
INCREASING EXPORT POTENTIAL OF CITRUS PRODUCTION: A CASE STUDY in CUKUROVA REGION
}

\begin{abstract}
In agriculture it is very important to take decisions. Especially big land farmers who export their products should be more careful about this process. This study is a unique study in the agricultural economics literature. The approach combines two methods AHP and Integer Programming. Face to face survey conducted with 115 farmers in the region who export Citrus. According to AHP results, farmers' answer generally did not change in terms of market selection. Considering production target prefer high income to low cost; quality to quantity. They prefer conventional production over other types of production. Certificated rootstock subsidy is the most important type of support for farmers. In addition, the most important support is marketing support. Considering Integer Programming results there are 7 farmers who are satisfied if they can get input support and per decare subsidy; if they can produce targeting quality and high income; if they choose biological production; if they can get payment security; if they can sell their products to international market with cooperative. Farmers' assigned to the groups number are low it shows that there is not a consensus among farmers.
\end{abstract}

Keywords: Citrus, Export, AHP, Integer Programming, Turkey

\section{Introduction}

When we think about a simple decision making problem, decision maker or individual should face with trade off and opportunity cost. Firstly, decision maker should calculate the cost which she / he did not choose and secondly she / he should predict the utility of her / his choice. It does not matter how simple the decision problem all process continues like this. But when it comes to various constraints and alternatives process gets more and more complicated. Especially agricultural production encloses various constraints and alternatives. Farmers who have large agricultural lands focus on export that makes farmers decisions more important. The economic sustainability of citrus farms in tough market conditions (low output prices, commercial conflicts and increasing institutional pressures for quality and environmental sustainability) is strongly dependent on their efficiency and productivity levels (Carrer, de Souza Filho, \& Batalha, 2017).

The center of this study is citrus producers who focus on export. Agricultural commodity export helps countries to stay in the positive side of international trade balance. As a result of its geographical position and climate condition Turkey is a very important country in terms of international citrus trade. Selected region is also very important in production and export. Around one in three citrus production of Turkey occurs in Cukurova Region. This study aims to analyze decisions of citrus farmers start from production

International Symposium on the Analytic Hierarchy Process
1

WEB CONFERENCE

DEC. 3 - DEC. 6,2020 
decision till selling decision. Furthermore farmers were asked to decide among different policies and agricultural supports. For analyzing Analytic Hierarchy Process (AHP) method is used. In the second stage of the study gathered criteria weights analyzed with Integer Programming to find the best satisfying solution. With the help of AHP method, titles such as policies, supports, production method, selling motive were used as criteria to build a decision system. Second stage of the study criteria weights used to find the best model which farmers satisfy. For model optimization Integer programming was used.

\section{Literature Review}

The Analytic Hierarchy Process is a method to derive ratio scales from both discrete and continuous pairwise comparisons. Unique part of this general theory of measurement is that measuring relative strength of preferences and feelings (Saaty, 1987). There is a gap in literature about decision making process for agricultural sector especially considering agricultural economics field. There is no such study focuses on policies, supports or production target. Alphonce (1997), mentioned in his study that the AHP method cover wide range of subjects especially in agriculture. Thomas et. al. (2011), tried to determine farmers preferences for firms, dealers or cooperatives in terms of economic and social benefits. Dragincic et.al. (2015), used AHP to evaluate and select table grape varieties intended for organic production

\section{Hypotheses/Objectives}

In the study 9 criteria and 25 alternatives were used to build decision system. First question is about market target. In other words which market (international or domestic) farmers focus to sell their products after that question questionnaire divided into two parts and farmers asked to consider AHP questions firstly considering the domestic market and then the international market.

After that analyze derived weights used to generate the farmer profiles with the best combination of alternatives. Second method is Integer Programming that will help optimization.

\section{Research Design/Methodology}

For data collection face to face survey method was used. Surveys were conducted with 115 citrus producers out of 1990 registered producers. Records, obtained from the Ministry of Food, Agriculture and Livestock. Respondents selected randomly among producers who are the decision makers of the production and selling process. In the Figure 1 AHP model of the study can be seen. Consistency ratios found not higher than 0,03 . That shows survey understood well. 
Figure 1 AHP Model of the Study

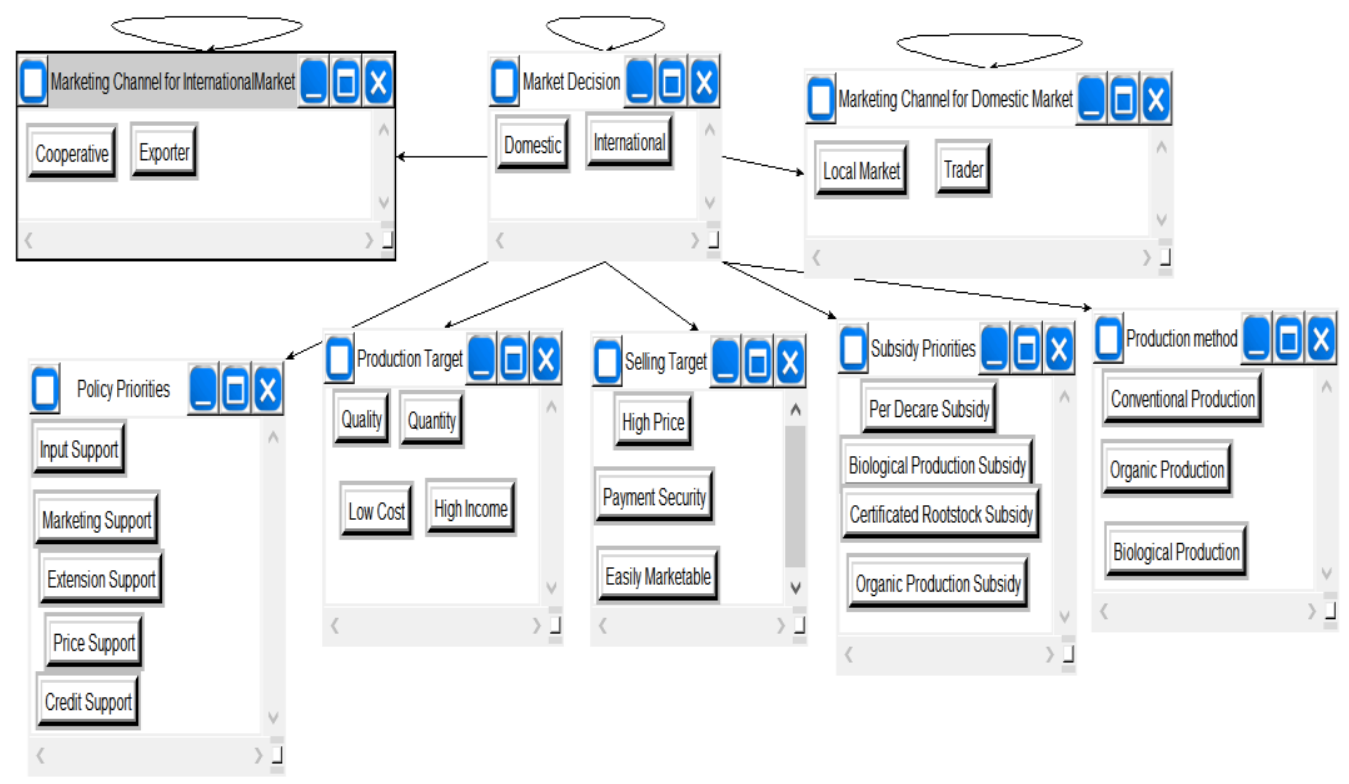

\section{Data/Model Analysis}

Farmers' answer generally did not change in terms of market selection. Considering production target prefer high income to low cost; quality to quantity. They prefer conventional production over other types of production. Certificated rootstock subsidy is the most important type of support for farmers. In addition, the most important support is marketing support. Nearly all of them mentioned about the importance of this support. Payment security is very important for them. About marketing channel decision in domestic market they prefer selling their products directly to local markets; in international market they prefer cooperative option which they are eager to build that kind of structure. Results can be seen in Table 1 . 
ISAHP Article: A Style Guide for Paper Proposals To Be Submitted to the International Symposium on the Analytic Hierarchy Process 2020, Web Conference.

Table 1 AHP Scores

\begin{tabular}{|l|c|c|}
\hline & \multicolumn{2}{|c|}{ Criteria } \\
\hline Alternatives & Domestic Market & International Market \\
& High Income & High Income \\
& 0,665 & 0,809 \\
\cline { 2 - 3 } & Quality & High Income \\
Production Target & 0,552 & 0,771 \\
\hline & & \\
Production Method & Conventional Prod. & Conventional Prod. \\
\hline \multirow{4}{*}{ Subsidy Priorities } & 0,499 & 0,439 \\
\hline \multirow{3}{*}{ Policies Priorities } & Certificated Rootstock & Certificated Rootstock \\
\hline \multirow{3}{*}{ Selling Target } & 0,329 & 0,322 \\
\hline \multirow{3}{*}{ Marketing Channel } & Marketing Support & Marketing Support \\
& 0,298 & 0,309 \\
\hline & Payment Security & Payment Security \\
& 0,414 & 0,365 \\
\hline
\end{tabular}

In the second part of the study the weights of alternatives used for optimization with integer programming. As a result of this analyze the first three models generated. These are shown in Table 2. For example in the first group there are 7 farmers who are satisfied if they can get input support and per decare subsidy; if they can produce targeting quality and high income; if they choose biological production; if they can get payment security; if they can sell their products to international market with cooperative.

Table 2 Optimum Scenarios

\begin{tabular}{|l|c|l|c|}
\hline Policies & Input Support & $\begin{array}{l}\text { Marketing } \\
\text { Support }\end{array}$ & $\begin{array}{l}\text { Marketing } \\
\text { Support }\end{array}$ \\
\hline Supports & $\begin{array}{c}\text { Per Decare } \\
\text { Subsidy }\end{array}$ & $\begin{array}{c}\text { Organic } \\
\text { Production } \\
\text { Subsidy }\end{array}$ & $\begin{array}{c}\text { Per Decare } \\
\text { Subsidy }\end{array}$ \\
\hline Production Target 1 & High income & High income & High income \\
\hline Production Target 2 & Quality & Quality & Quality \\
\hline Selling Target & $\begin{array}{c}\text { Payment } \\
\text { Security }\end{array}$ & $\begin{array}{c}\text { Payment } \\
\text { Security }\end{array}$ & $\begin{array}{c}\text { Payment } \\
\text { Security }\end{array}$ \\
\hline Production Method & $\begin{array}{c}\text { Biological } \\
\text { Prod. }\end{array}$ & Organic Prod. & $\begin{array}{l}\text { Conventional } \\
\text { Prod. }\end{array}$ \\
\hline Market & Int. Market & Int. Market & Int. Market \\
\hline Marketing Channel (INT) & Cooperative & Cooperative & Cooperative \\
\hline Marketing Channel (DOM) & Local Market & Local Market & Local Market \\
\hline $\begin{array}{l}\text { Total Number of Decision Making Unit } \\
\text { (DMU): 115 }\end{array}$ & 7 & 7 & 5 \\
\hline $\begin{array}{l}\text { Total DMU's assigned to the group: } 19 \\
\text { (16,3\%) }\end{array}$ & $6,0 \%$ & $6,0 \%$ & $4,3 \%$ \\
\hline
\end{tabular}


ISAHP Article: A Style Guide for Paper Proposals To Be Submitted to the International Symposium on the Analytic Hierarchy Process 2020, Web Conference.

\section{Limitations}

Study have few limitations. First of all, study conducted with only 140 farmers. Some surveys were not consistent and these are excluded from study as a result 115 farmers were included to the study. The number of farmers can be increased in the future studies and area can be expanded. Another suggestion for future studies is that farmer profile can be change. Because of export motivation study conducted with farmers who export their products and have bigger land (bigger than $50 \mathrm{da}$.)

\section{Conclusions}

Studies using AHP in agricultural economics are limited. That fact was one of the reasons why we want to develop this study. On the other hand that fact affect the study negatively. After interviewing with all farmers with face to face it can be said that observations in the field are in line with results of the study. Farmers are very stressed about selling their products both international and domestic market for that reason cooperative is the most important marketing channel for them. In relation to this farmers also gave the biggest importance to marketing support. There is not a professional export establishment. They gave importance to quality based production and they do not prefer credit support which can be read as farmers do not want to be in the cycle of credit. They prefer direct government supports. In the second part of the paper 3 models generated as

mentioned before and number of farmers assigned to the groups found low (The sum of three groups is 19). The reason of that, farmers are not in a general consensus about issues. That affects negatively to move them together and establish a cooperative.

According to the results, it is concluded that may improve the decision making process of farmers and gathered results would be beneficial for government and other institutions to generate new policies.

\section{Key References}

Alphonce, C. B. (1997). Application of the analytic hierarchy process in agriculture in developing countries. Agricultural systems, 53(1), 97-112.

Carrer, M. J., de Souza Filho, H. M., \& Batalha, M. O. (2017). Factors influencing the adoption of Farm Management Information Systems (FMIS) by Brazilian citrus farmers. Computers and Electronics in Agriculture, 138(Supplement C), 11-19. doi: https://doi.org/10.1016/j.compag.2017.04.004

Dragincic, J., Korac, N., \& Blagojevic, B. (2015). Group multi-criteria decision making (GMCDM) approach for selecting the most suitable table grape variety intended for organic viticulture. Computers and Electronics in Agriculture, 111, 194-202.

Saaty, R. W. (1987). The analytic hierarchy process - what it is and how it is used. Mathematical modelling, 9(3-5), 161-176. 